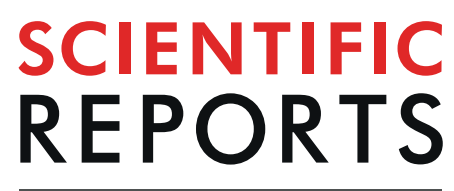

natureresearch

\title{
OPEN Author Correction: Enabling cell recovery from 3D cell culture microfluidic devices for tumour microenvironment biomarker profiling
}

\author{
María Virumbrales-Muñoz, Jose M. Ayuso, Alodia Lacueva, Teodora Randelovic, \\ Megan K. Livingston, David J. Beebe, Sara Oliván, Desirée Pereboom, Manuel Doblare, \\ Luis Fernández \& Ignacio Ochoa
}

Correction to: Scientific Reports https://doi.org/10.1038/s41598-019-42529-8, published online 17 April 2019

The Acknowledgements section in this Article is incomplete.

"Authors would like to thank Dr Edorta Santos for assistance on hydrogel degradation conditions, Inés Mármol for enriching discussions on the qPCR experiments and Jacobo Ayensa for valuable advice on statistical analysis. This work has been supported by the Spanish national research program (DPI2015-65401-C3-1-R and BIO201679092-R grants) and the Aragon Government (T24_17R grant). The Spanish national government provided M.V. studentship. Authors would like to acknowledge the use of Servicio General de Apoyo a la Investigación-SAI, Universidad de Zaragoza. ORCHID and CISTEM projects have received funding from $\mathrm{H} 2020$ programme under grant agreement 766884 and 778354 respectively."

should read:

"Authors would like to thank Dr Edorta Santos for assistance on hydrogel degradation conditions, Inés Mármol for enriching discussions on the qPCR experiments and Jacobo Ayensa for valuable advice on statistical analysis. This work has been supported by the Spanish national research program (DPI2015-65401-C3-1-R and BIO201679092-R grants) and the Aragon Government (T24_17R grant). The Spanish national government provided M.V. studentship. Authors would like to acknowledge the use of Servicio General de Apoyo a la Investigación-SAI, Universidad de Zaragoza. ORCHID and CISTEM projects have received funding from H2020 programme under grant agreement 766884 and 778354 respectively. M.V., D.J.B and M.K.L. acknowledge University of Wisconsin Carbone Cancer Center Support Grant P30 CA014520, Environmental Protection Agency 83573701-Human Models for Analysis of Pathways (H-MAPs) Center and NIH NCI Cancer Moonshot Grant R33CA225281."

(c) (i) Open Access This article is licensed under a Creative Commons Attribution 4.0 International License, which permits use, sharing, adaptation, distribution and reproduction in any medium or format, as long as you give appropriate credit to the original author(s) and the source, provide a link to the Creative Commons license, and indicate if changes were made. The images or other third party material in this article are included in the article's Creative Commons license, unless indicated otherwise in a credit line to the material. If material is not included in the article's Creative Commons license and your intended use is not permitted by statutory regulation or exceeds the permitted use, you will need to obtain permission directly from the copyright holder. To view a copy of this license, visit http://creativecommons.org/licenses/by/4.0/.

(C) The Author(s) 2020 